\title{
Inflamasom NLRP3 jako czynnik sprawczy i ochronny w patogenezie nieswoistych chorób zapalnych jelit
}

\section{Mikołaj Świerczyński,}

Jakub Fichna ${ }^{\square}$

Zakład Biochemii, Wydział Lekarski, Uniwersytet Medyczny w Łodzi

https://doi.org/10.18388/pb.2020_354

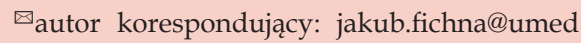
lodz.pl

Słowa kluczowe: Inflamasom NLRP3, nieswoiste choroby zapalne jelit, choroba Leśniowskiego-Crohna, wrzodziejące zapalenie jelita grubego

Wykaz najważniejszych stosowanych skrótów: ASC - białko adaptorowe ASC (ang. adaptor-apoptosis-associated-speck-like protein); CARD - domena aktywacji i rekrutacji kaspaz (ang. caspase recruitment domain); ChLC - choroba Leśniowskiego-Crohna; DAMP - wzorce molekularne związane z uszkodzeniem (ang. damage associated molecular patterns); NACHT - domena NACHT (NAIP, CIITA, HET-E, TEP1); NChZJ - nieswoiste choroby zapalne jelit; NLRP3 - białko NOD-podobne 3, zawierające domenę pirynową (ang. NOD-like receptor family, pyrin domain containing 3); PAMP wzorce molekularne związane $\mathrm{z}$ patogenami (ang. pathogen associated molecular patterns); PYD - domena pirynowa; WZJG - wrzodziejące zapalenie jelita grubego.

Oświadczenia: Autorzy deklarują brak konfliktu interesu.

Finansowanie: Praca finansowana $\mathrm{z}$ "Grantu UMEDu 2019" przyznanego Mikołajowi Świerczyńskiemu (564/1-000-00/564-20-033) oraz działalności statutowej Zakładu Biochemii (503/1-156-04/503-11-001-19-00).

\section{STRESZCZENIE}

Tieswoiste choroby zapalne jelit (NChZJ) stanowią grupę chorób przewlekłych o globalnym zasięgu, znacznie obniżających jakość życia pacjentów. Do głównych przedstawicieli NChZJ zalicza się chorobę Leśniowskiego-Crohna (ChLC) oraz wrzodziejące zapalenie jelita grubego (WZJG). Chociaż etiologia NChZJ nadal pozostaje nie $\mathbf{w}$ pełni poznana, inflamasom NLRP3 jest jednym z najbardziej obiecujących kierunków badań w jej zakresie. NLRP3 jest aktywowanym przez molekularne wzorce związane z uszkodzeniem komórki i patogenami funkcjonalnym kompleksem odpowiedzialnym za produkcję cytokin proza-

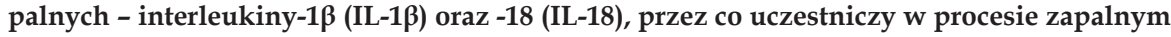
leżącym u podłoża NChZJ. W ostatnich latach coraz częściej zwraca się jednak uwagę na aktywność NLRP3 obejmującą utrzymywanie homeostazy błony śluzowej jelit oraz kontroli składu mikrobiomu jelitowego, dzięki której może on stanowić ważny czynnik ochronny przed NChZJ. W niniejszym artykule przedstawiamy wyniki badań przemawiające za każdą $\mathrm{z}$ przedstawionych teorii na temat NLRP3 $\mathrm{w}$ patogenezie NChZJ - zarówno jako czynnika sprawczego, jak i ochronnego.

\section{WPROWADZENIE - NIESWOISTE CHOROBY ZAPALNE JELIT}

Nieswoiste choroby zapalne jelit (NChZJ) stanowią grupę przewlekłych chorób o przebiegu charakteryzującym się naprzemiennymi okresami remisji i zaostrzeń, co ostatecznie przekłada się na znacznie obniżoną jakość życia pacjentów cierpiących na te choroby. Do głównych przedstawicieli NChZJ zalicza się chorobę Leśniowskiego-Crohna (ChLC) oraz wrzodziejące zapalenie jelita grubego (WZJG) różniące się lokalizacją oraz rozległością zapalenia w obrębie ściany w przewodzie pokarmowym [1].

Etiologia NChZJ nadal pozostaje nie w pełni poznana, jednak wśród czynników mających najlepiej udokumentowany wpływ wymienia się funkcjonowanie bariery nabłonka błony śluzowej jelit, skład mikrobiomu jelitowego, czynniki środowiskowe (np. dietę, palenie tytoniu) bądź genetyczne. Do kontynentów najbardziej dotkniętych problemem NChZJ należą Europa oraz Ameryka Pólnocna; szacuje się $\mathrm{w}$ nich odpowiednio 2,2 oraz 1,5 miliona przypadków tych schorzeń. W ostatnich latach rośnie liczba przypadków nieswoistych chorób zapalnych jelit w krajach o niższej dotychczas zachorowalności, np. krajach Azji Wschodniej, co wiąże się z globalnym upowszechnianiem się zachodniego stylu życia, obejmującym ograniczenie aktywności fizycznej oraz wysokokaloryczną dietę z wysoką zawartością tłuszczu [2]. Podsumowanie podstawowych informacji na temat NChZJ zostało przedstawione w Tabeli 1.

Jednym z najbardziej obiecujących kierunków badań na temat patogenezy oraz podłoża molekularnego NChZJ są prace rozwijające wiedzę na temat stanu zapalnego, który jest istotą obserwowanych objawów . Centralną rolę w jego powstawaniu odgrywają inflamasomy, wśród których najlepiej udokumentowany udział w patogenezie NChZJ ma inflamasom NLRP3 (ang. NOD-like receptor family, pyrin domain containing 3). Inflamasomy to grupa wewnątrzkomórkowych kompleksów zlokalizowanych w cytozolu, będących elementem odporności nieswoistej, odpowiedzialnych za wykrywanie molekularnych wzorców wskazujących zarówno na uszkodzenie komórki (ang. damage associated molecular patterns, DAMP), jak i na obecność patogenów powodujących infekcję (ang. pathogen associated molecular patterns, PAMP) oraz produkcję cytokin prozapalnych [4].

Pomimo wcześniej postulowanej roli inflamasomu NLRP3 jako sprawczego czynnika indukującego i podtrzymującego proces zapalny w przebiegu NChZJ, w ostatnich latach coraz częściej zwraca się uwagę na potencjalne ochronne działanie tego inflamasomu polegające na jego udziale w utrzymywaniu homeostazy błony śluzowej jelit. 


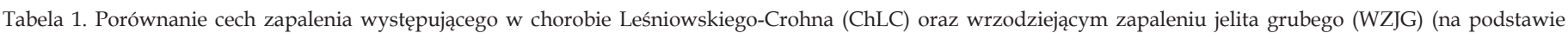
Hendrickson i in. [3])

\begin{tabular}{lll}
\hline Cecha & ChLC & WZJG \\
& $\begin{array}{l}\text { Najczęściej terminalna część jelita krętego. } \\
\text { Zróżnicowana w obrębie całego przewodu } \\
\text { pokarmowego, możliwość jednoczesnego } \\
\text { występowania ognisk chorobowych } \\
\text { rozdzielonych odcinkami niezmienionego } \\
\text { przewodu pokarmowego (tzw. 'skip areas') }\end{array}$ & $\begin{array}{l}\text { Dystalna czéść okrężnicy skąd proces szerzy } \\
\text { się w sposób ciągły w stronę proksymalną } \\
\text { okrężnicy, obejmując czasami terminalną } \\
\text { część jelita krętego (ang. backwash ileitis) }\end{array}$ \\
\hline Rozległość zapalenia & Pełnościenne & Głównie ograniczone do błony śluzowej \\
\hline Cechy histologiczne nacieku & Nieserowaciejące ziarniniaki & Naciek granulocytarny \\
\hline Odpowiedź immunologiczna & Th1/Th17-zależna & Th2-zależna
\end{tabular}

\section{INFLAMASOMY}

Głównym elementem łączącym inflamasomy jest ich ogólna organizacja - każdy inflamasom składa się z: 1) cząsteczki pełniącej rolę sensora, 2) białka adaptorowego oraz 3) enzymu efektorowego (kaspaza 1) odpowiedzialnego za produkcję cytokin prozapalnych - interleukiny $1 \beta$ (IL-1 $\beta$ ) oraz IL-18 z ich prekursorów (odpowiednio pro-IL-1 $\beta$ oraz pro-IL-18). Nazwy poszczególnych inflamasomów tworzy się z reguły od występującego w ich strukturze białka sensorowego. Zdecydowana większość ze znanych obecnie inflamasomów posiada białko sen- sorowe należące do rodziny NLR (ang. Nucleotide oligmerization domain (NOD)-like receptor family), składającej się z 23 białek, w tym z omawianego w artykule białka NLRP3 oraz pokrewnych mu NLRP1, NLRP6, NLRP7, NLRP8, NLRP12 czy NLRC4. Ponadto, istnieją również inflamasomy, które w roli sensora posiadają białka takie jak AIM2 (ang. absent in melanoma 2), IFI16 (ang. IFN $\gamma$-inducible protein 16) czy RIG-I (ang. retinoic acid-inducible gen I). Specyfika poszczególnych białek receptorowych oraz posiadane przez nie funkcjonalne domeny determinują ich swoistość względem konkretnych sygnałów aktywujących [5].

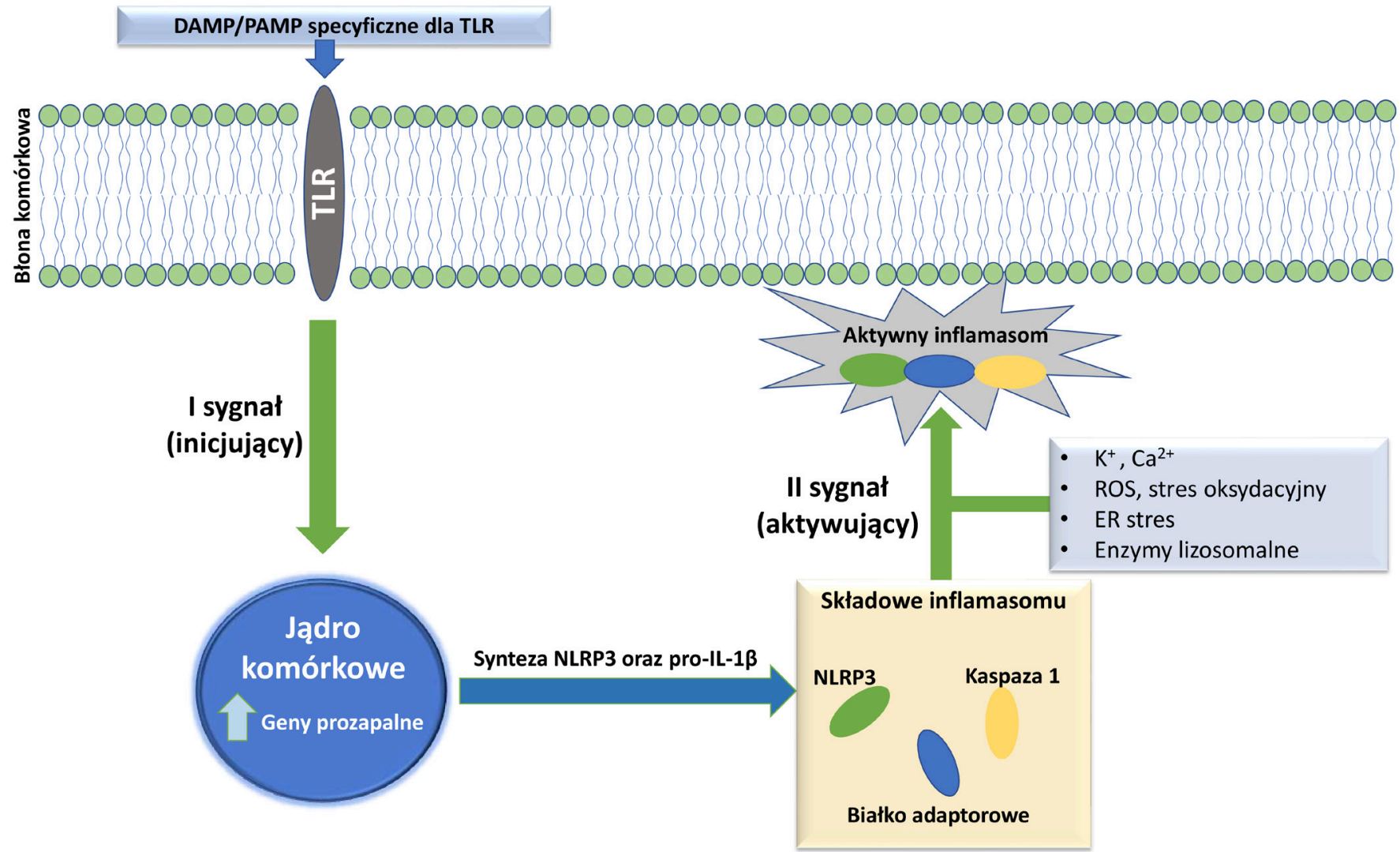

Rycina 1. Schemat dwustopniowego powstawania i aktywacji inflamasomu NLRP3. 


\section{LRRs}

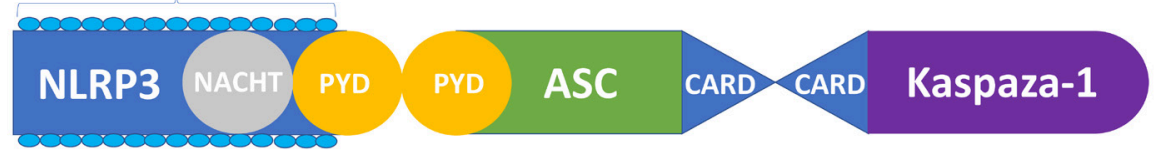

Rycina 2. Budowa inflamasomu NLRP3.

ASC - adaptor-apoptosis-associated-speck-like protein; CARD - caspase recruitment domain; LRRs - lysin-rich-repeats; NACHT - domena NACHT (NAIP, CIITA, HET-E, TEP1); NLRP3 - NOD-like receptor family, pyrin domain containing 3; PYD - pyrin domain.
W badaniach na mysich makrofagach wykazano, że powstawanie i aktywacja inflamasomu zachodzi w sposób dwuetapowy - najpierw na skutek sygnału inicjującego pochodzącego z receptorów Toll-podobnych (ang. Toll-like receptors, TLR) dochodzi do indukcji prozapalnych czynników transkrypcyjnych, zwłaszcza NF-кB (ang. nuclear factor kappa-light-chain-enhancer of activated B cells) czy cytokin takich jak TNF czy IL-1 [6], na skutek której zwiększa się produkcja składowych inflamasomu. Receptory TLR są receptorami wykazującymi ekspresję w błonie komórkowej, odpowiedzialnymi za specyficzne dla danego TLR wykrywanie DAMP i PAMP. Obecnie wykazano ekspresję co najmniej 10 receptorów TLR u człowieka oraz 12 u myszy [7].

Po zadziałaniu drugiego sygnału - sygnału aktywującego, dochodzi do bezpośredniej aktywacji sensora i procesu składania kompleksu w funkcjonalną całość[8]. Sygnał aktywujący może pochodzić z różnych wewnątrzkomórkowych ścieżek sygnałowych poprzez takie czynniki jak: 1) napływ jonów potasowych $\left(\mathrm{K}^{+}\right)$oraz wapniowych $\left.\left(\mathrm{Ca}^{2+}\right), 2\right)$ tworzenie reaktywnych form tlenu (ang. reactive oxygen species, ROS) oraz stres oksydacyjny komórki, 3) stres retikulum endoplazmatycznego (ang. ER stress) na skutek akumulacji nieprawidłowo sfałdowanych białek, 4) działanie enzymów lizosomalnych [9]. Uproszczony schemat przedstawiający proces aktywacji inflamasomu NLRP3 został przedstawiony na rycinie 1 .

\section{INFLAMASOM NLRP3}

Obecnie najlepiej opisanym inflamasomem zaangażowanym w patogenezę NChZJ jest inflamasom NLRP3, którego ekspresję wykazano w komórkach układu immunologicznego oraz nierogowaciejących komórkach nabłonkowych pokrywających błony śluzowe głównie w obrębie nosogardła, przełyku oraz zewnętrznej części szyki macicy, jak również nabłonku urotelialnym w pęcherzu moczowym [10]. W obrębie jelita grubego NLRP3 wykazuje ekspresję w komórkach nabłonkowych [11] oraz fagocytach jednojądrzastych w obrębie blaszki właściwej błony śluzowej (łac. lamina propria) [12]. Odpowiada on za produkcję kluczowych dla patogenezy NChZJ IL-1 $\beta$ oraz IL-18 [13] w odpowiedzi na sygnały należące do DAMP oraz PAMP (Tabela 2).

Tabela 2. Przykłady wzorców molekularnych aktywujących inflamasom NLRP3 [14]-[16].

\begin{tabular}{ll} 
DAMP & PAMP \\
Jony K+ & Lipopolisacharyd (LPS) \\
\hline Kryształy kwasu moczowego (MSU) & Bakteryjne RNA \\
Reaktywne formy tlenu & MDP \\
ATP & Poly I:C (analog dsRNA) \\
Amyloid & \\
\hline
\end{tabular}

Inflamasom NLRP3 jest kompleksem białkowym składającym się trzech zasadniczych elementów: 1) białka NLRP3 pełniącego rolę sensora, 2) białka adaptorowego ASC (ang. adaptor-apoptosis-associated-speck-like protein) oraz 3) kaspazy 1 stanowiącej składnik efektorowy kompleksu. Białko NLRP3 pełni funkcję sensora dzięki obecnym w jego strukturze domenom bogatym w powtórzenia lizynowe (ang. Lysin-rich-repeats, LRRs). Ponadto, w swojej strukturze posiada domenę NACHT (nazwa pochodząca od jej składowych: NAIP, CIITA, HET-E oraz TEP1), wykazującą aktywność ATPazy i odpowiadającą za oligomeryzację kompleksu oraz domenę pirynową (PYD), która poprzez interakcję z analogiczną domeną w białku ASC uczestniczy w tworzeniu połączenia między tymi białkami. W białku ASC obecna jest również domena CARD (ang. caspase recruitment domain), która jest niezbędna do przyłączenia i uzyskania funkcji przez kaspazę 1, odpowiedzialną za następczą produkcję prozapalnych cytokin - IL-1 $\beta$ oraz IL-18 z ich form prekursorowych (odpowiednio pro-IL-1 $\beta$ oraz pro-IL-18). Warto wspomnieć, że do procesu łączenia inflamasomu NLRP3 w kompleks wymagana jest obecność białka NEK7 (ang. NIMA related kinase 7), będącego kinazą serynowo-treoninową, która poprzez mostkowane sąsiednich podjednostek białka NLRP3 promuje jego oligomeryzację [17]. Budowa inflamasomu została schematycznie przedstawiona na rycinie 2.

\section{AKTYWNOŚĆ INFLAMASOMU NLRP3 I JEJ WPEYW NA NCHZJ}

Inflamasom ze względu na zapalny charakter NChZJ jest silnie powiązany z patogenezą tych chorób. Lazaridis wraz z zespołem [18] przeprowadzili badanie, w którym określili ogólnoustrojową aktywność tego inflamasomu w jednojądrowych komórkach odpornościowych z krwi obwodowej (ang. peripheral blood mononuclear cells, PBMC) u pacjentów z ChLC oraz WZJG porównując uzyskane wartości do grupy kontrolnej, którą stanowili zdrowi ochotnicy. Następnie autorzy badania oznaczyli ilościowo produkcję IL-1 $\beta$ przez PBMC traktowane 1) LPS + MSU lub 2) samym LPS. Aktywacja inflamasomu definiowana była jako wzrost produkcji IL-1 $\beta$ w grupie LPS+MSU o co najmniej 30\% w porównaniu do komórek traktowanych samym LPS.

W przeprowadzonym badaniu aktywacja inflamasomu została wykryta u $60 \%$ pacjentów z ChLC, co było wartością istotnie wyższą statystycznie od wyniku uzyskanego w grupie kontrolnej (28,6\%). Aktywacja inflamasomu znacząco częściej występowała również u pacjentów z WZJG (55\%), jednak wynik nie okazał się statystycznie istotny w porównaniu z grupą kontrolną. Również ilościowy pomiar wzrostu stężenia IL-1 $\beta$ wykazał istotny wzrost jedynie w grupie pacjentów chorych na ChLC. Co ciekawe, aktywacja inflamasomu w przebiegu ChLC nie korelowała z czasem 
trwania choroby, ani innymi czynnikami takimi jak płeć, palenie papierosów czy lokalizacja zmian. W przypadku WZJG wykazano jednak, że aktywacja inflamasomu jest istotnie częstsza wśród pacjentów z dłużej trwającą chorobą (ponad 1,5 roku).

Zbadano również związek między poziomem IL-1 $\beta$ a aktywnością choroby - eksperyment przeprowadzony na biopsjach jelita grubego wykazal, że próbki pobrane od pacjentów w ostrej fazie WZJG charakteryzowały się wyższymi poziomami tej cytokiny niż próbki pobrane w remisji choroby [19].

Obecnie istnieją dwa podejścia do roli inflamasomu $\mathrm{w}$ patogenezie NChZJ. Zakładają one, że 1) wzrost aktywności inflamasomu może być bezpośrednią przyczyną powstania zapalenia odpowiedzialnego za rozwój choroby i jej objawów oraz 2) inflamasom jest "strażnikiem” homeostazy błony śluzowej oraz odpowiada za jej integralność, a zatem ewentualny wzrost jego aktywności byłby zjawiskiem korzystnym.

\section{INFLAMASOM NLRP3 JAKO CZYNNIK SPRAWCZY W PATOGENEZIE NCHZJ}

Aktywność prozapalna głównych cytokin efektorowych inflamasomu stanowi podstawę hipotezy zakładającej czynny udział inflamasomu w rozwoju NChZJ i ich objawów. W mysich modelach NChZJ (odpowiadających zarówno WZJG, jak i ChLC) wykazano, że myszy pozbawione ekspresji NLRP3 przechodziły chorobę łagodniej oraz z niższą śmiertelnością niż myszy kontrolne [20].

Od dawna wiadomo, że w błonie śluzowej jelita grubego objętej stanem zapalnym produkcja IL-1 $\beta$ znacząco wzrasta [21]. IL-1 $\beta$ jest produkowana przez komórki jednojądrzaste - głównie makrofagi oraz monocyty, które na skutek ogólnoustrojowych sygnałów rozpoczynają jej wzmożoną produkcję nawet przed przejściem do tkanek jelita, będąc jeszcze w krwiobiegu [22]. Źródła tych sygnałów można upatrywać również w aktywności inflamasomu - Christ i in. [23] wykazali w mysim modelu miażdżycy, że wysokokaloryczna dieta - tzw. dieta zachodnia (ang. western diet), będąca jednym z głównym czynników ryzyka NChZJ, powoduje epigenetyczne przeprogramowanie komórek odporności wrodzonej oraz wywołuje ogólnoustrojowy stan zapalny, którego centralnym mediatorem jest właśnie NLRP3. IL-1 $\beta$ może być ponadto wydzielana przez komórki zrębowe, komórki pnia oraz komórki nowotworowe [24].

Aktywność IL-1 $\beta$ cechuje znaczna plejotropia przejawiająca się w zdolności tej cytokiny do indukcji chemotaksji neutrofili, proliferacji limfocytów T, wydłużenia ich życia oraz różnicowania $\mathrm{w}$ kierunku limfocytów pomocniczych, głównie typu Th17 [25], które obserwuje się w ChLC obok Th1 [26]. Jednakże IL-1 $\beta$ jest czynnikiem niezbędnym do wywołania ostrego zapalenia niezależnie od tego, czy przebiega ono $\mathrm{w}$ mechanizmie nieswoistym czy swoistym $\mathrm{z}$ zaangażowaniem limfocytów T [27]. Na poziomie molekularnym IL-1 $\beta$ zwiększa bowiem ekspresję takich czynników jak NF-кB czy kinaza MAPK (ang. mitogen-activated protein kinase), z udziałem których jest w stanie indukować produkcję innych cytokin o działaniu prozapalnym [4]. Jedną z le- piej opisanych zależności jest kinetyka syntezy IL-6, która koreluje z kinetyką syntezy IL-1 $\beta$ i ją odzwierciedla [18].

Warto zauważyć, że dzięki podobieństwu strukturalnemu IL-1 $\beta$ oraz IL-18 możliwa jest produkcja obu tych interleukin przez kaspazę 1, która bezpośrednio łączy je z aktywnością inflamasomu [28].

IL-18 jest wielokierunkowo działającą cytokiną wykazującą również działanie prozapalne. Przejawia się ono głównie w zdolności do indukcji syntezy interferonu $\gamma$ (IFNץ) oraz promowaniu odpowiedzi immunologicznej zależnej od komórek Th1, podobnie jak ma to miejsce w przypadku ChLC [29]. W tym aspekcie kluczowa okazuje się interakcja z IL-12, która działa synergistycznie z IL-18, co prowadzi do wzmożonej produkcji IFNץ. Natomiast przy braku IL12, IL-18 wykazuje tendencję do indukcji wydzielania IL-4 oraz promowania odpowiedzi immunologicznej typu Th2 IL-4-zależnej. Takie działanie IL-18 może być dodatkowo wspomagane przez IL-2 [30]. Na poziomie molekularnym interakcja IL-18 z jej receptorem (IL-18R) prowadzi do uaktywnienia kinaz inhibitora $\kappa \mathrm{B}(\mathrm{IKK})$ - IKK $\alpha$ oraz IKK $\beta$. Enzymy te odpowiadają za fosforylację unieczynniającą wspomniany inhibitor $\kappa \mathrm{B}$, co znosi jego hamujące działanie na zależną od NFкB ekspresję genów czynników prozapalnych [31].

Istnieją badania sugerujące niekorzystny wpływ IL-18 na patogenezę NChZJ. W mysich modelach WZJG indukowanych za pomocą soli sodowej siarczanu dekstranu (DSS) wykazano, że myszy pozbawione ekspresji genów IL-18 oraz IL-18R są chronione przed rozwojem procesu zapalnego [31], aczkolwiek wyniki te nie są jednoznaczne $\mathrm{z}$ powodu odwrotnych wniosków uzyskanych z podobnych eksperymentów [32]. Ponadto, Nowarski wraz z zespołem [31] wykazali, że w mysim modelu WZJG brak negatywnego regulatora IL-18 - białka wiążącego IL-18 (ang. IL-18 binding protein, IL-18bp) prowadzi do znacznego zaburzenia dojrzewania i zmniejszenia populacji komórek kubkowych, a w konsekwencji większej aktywności choroby. Warto zauważyć, że w opisanym modelu stan wzmożonej aktywności IL-18 został osiągnięty przy fizjologicznych poziomie tej cytokiny. Efektu tego nie zaobserwowano u myszy pozbawionych zarówno IL-18bp, jak i IL-18R.

Zależność pomiędzy podwyższoną aktywnością IL-18 oraz cięższym przebiegiem NChZJ została wykazana również w badaniach klinicznych - Pizzaro wraz z zespołem [33] przeprowadzili badanie oceniające ekspresję IL-18 w biopsjach jelita grubego pacjentów chorujących na ciężką postać ChLC oraz WZJG, jak również materiale od zdrowej grupy kontrolnej. W badaniu ekspresja IL-18 była istotnie wyższa w grupie chorych na ChLC w porównaniu do wartości uzyskanych dla dwóch pozostałych grup.

Warto odnotować, że cząsteczka NLRP3, w mechanizmie niezależnym od inflamasomu jako kompleksu, jest uważana za ważny czynnik transkrypcyjny w procesie różnicowania limfocytów w kierunku typu Th2, które są głównymi modulatorami odpowiedzi immunologicznej charakterystycznej dla WZJG. Poprzez interakcję z czynnikiem transkrypcyjnym IRF4, NLRP3 zwiększa jego zdolność do aktywacji 
promotora genu dla IL-4 ważnej dla różnicowania limfocytów Th2 [34].

Z perspektywy patogenezy NChZJ istotne jest, że zarówno IFNץ, jak i IL-4 uznawane są za czynniki o negatywnym wpływie na barierę nabłonkową w przewodzie pokarmowym, przyczyniające się do zwiększenia jej przepuszczalności. Badanie przeprowadzone przez Di Leo wraz z zesp. [35] wykazały, że eksperymentalne monowarstwy z komórek T84 poddane działaniu IL-4 wykazały istotne obniżenie oporności przeznabłonkowej (ang. transepithelial resistance, TER). Biorąc pod uwagę fakt, że NLRP3 może wpływać na zwiększenie produkcji IL-4 przynajmniej na dwa sposoby - poprzez IL-18 oraz (w sposób bezpośredni) IL-4 - jej powiązanie z NChZJ może być czynnikiem wartym większej uwagi w kontekście rozważań na temat inflamasomu.

Dowodów na istotny udział NLRP3 w indukowaniu stanu zapalnego obserwowanego w NChZJ dostarczają badania na temat jego negatywnej regulacji. MikroRNA (miRNA) należą do najważniejszych regulatorów aktywności genów. Są to niekodujące, jednoniciowe oraz endogenne cząsteczki RNA działające poprzez parowanie z kodującymi fragmentami matrycowego RNA. Sztandarowym przykładem miRNA związanego z NChZJ jest miR-223, którego podwyższone poziomy odnotowuje się w biopsjach pobranych od chorych i którego zdolność do regulacji NLRP3 została wykazana in vitro [36]. Neudecker wraz z zespołem [37] przeprowadzili badanie w mysim modelu DSS oceniające wpływ regulacji stanu zapalnego przez miR-223. Wykazano, że u myszy pozbawionych funkcjonalnego miR-223 w porównaniu z grupą kontrolną rozwinęła się choroba o znacznie cięższym przebiegu, charakteryzująca się większą utratą masy ciała, wyższym indeksem aktywności choroby oraz bardziej zaawansowanymi zmianami histopatologicznymi.

Innym negatywnym regulatorem funkcji inflamasomu jest białko CARD8, które bezpośrednio łączy się z białkiem NLRP3 w czasie aktywacji inflamasomu i blokuje jego połączenie z białkiem adaptorowym ASC [38]. Odkryto rzadką unieczynniającą mutację genu CARD8 mogącą powodować ChLC [39] z charakterystyczną nadmierną produkcją IL-1 $\beta$ wpływającą na ujawnienie się choroby oraz jej cięższy przebieg [39]. Co istotne, wariant choroby związany z tą mutacją nie odpowiadał na terapię lekami biologicznymi z grupy anty-TNF, które są uwzględniane w schematach leczenia NChZJ. Skuteczne okazały się inhibitory IL-1 $\beta$, które poprawiały stan kliniczny pacjentów oraz obniżały poziomy cytokin prozapalnych (IL-1 $\beta$, IL-6 oraz TNF), nie wpływając jednak na patologiczny $\mathrm{w}$ tym przypadku poziom aktywności inflamasomu.

Co ciekawe, w 2014 roku został opisany przypadek rodziny noszącej aktywującą mutację innego białka należącego do rodziny NLR - białka NLRC4 [40]. Mutacja ta była odpowiedzialna za wywołanie zespołu chorobowego, w skład którego wchodziło zapalenie jelit typu nieinfekcyjnego enterocolitis rozpoczynające się $\mathrm{w}$ okresie neonatalnym z towarzyszącą okresową gorączką oraz ciężkimi epizodami autozapalnymi. Badanie to, choć nie dotyczyło NLRP3 bezpośrednio, stanowi kolejny dowód na aktywny udział nadmiernej aktywności kompleksów inflamasomów w patogenezie procesów zapalnych w obrębie przewodu pokarmowego.

Teoria traktująca inflamasom jako czynnik odpowiedzialny za patologiczny stan zapalny stanowi podstawę do postawienia go w roli celu dla leczenia farmakologicznego. Najlepiej poznanym związkiem bezpośrednio blokującym oligomeryzację NLRP3 jest MCC950. Dokładny mechanizm jego działania polega na blokowaniu domeny NACHT w białku NLRP3 przez co niemożliwe stają się zmiany konformacyjne oraz interakcje $\mathrm{z}$ innymi składnikami kompleksu [41]. Skuteczność MCC950 została wykazana w mysim modelu WZJG [42], co stanowi obiecującą perspektywę dla dalszych badań nad sprawczym aspektem aktywności inflamasomu NLRP3 w przebiegu patogenezy NChZJ oraz możliwego zastosowania bezpośrednich inhibitorów inflamasomu w praktyce klinicznej.

Najważniejsze mechanizmy aktywności inflamasomu NLRP3 jako czynnika sprawczego w patogenezie nieswoistych chorób zapalnych jelit zostały podsumowane w Tabeli 3 .

\section{INFLAMASOM NLRP3 JAKO CZYNNIK OCHRONNY PRZED NCHZJ}

W ostatnich latach teoria mówiąca o niekorzystnym wpływie aktywności inflamasomu na przebieg NChZJ jest poddawana ponownej ocenie. Dzieje się tak za sprawą nowych doniesień odnośnie aktywności produkowanych przez inflamasom NLRP3 cytokin efektorowych - IL-1 $\beta$ oraz IL-18 odgrywających rolę w utrzymywaniu homeostazy w obrębie przewodu pokarmowego poprzez kontrolę integralności bariery nabłonka jelitowego oraz modulowanie odpowiedzi immunologicznej na mikrobiotę znajdującą się w świetle jelita.

Tabela 3. Podsumowanie najważniejszych mechanizmów aktywności inflamasomu NLRP3 jako czynnika sprawczego w patogenezie NChZJ

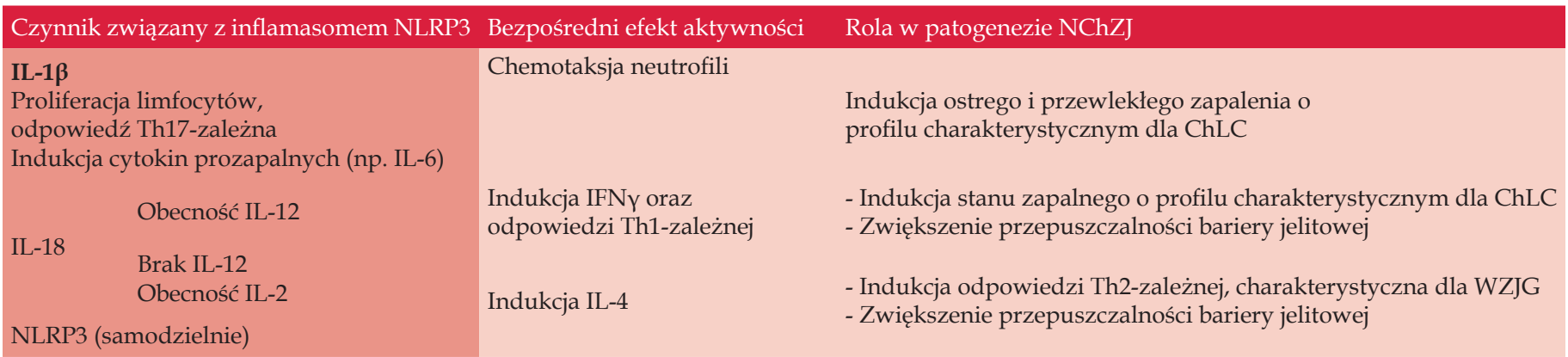


Yao wraz z zespołem [12] wykazali, iż aktywująca mutacja NLRP3 R258W powoduje powstanie oporności na eksperymentalnie indukowane WZJG. Myszy noszące powyższą mutację po traktowaniu roztworem DSS były w lepszym stanie ogólnym niż myszy kontrolne typu dzikiego - w grupie badanej odnotowano istotnie mniejszy ubytek masy ciała, niższe indeksy aktywności choroby oraz mniejsze skrócenie długości jelita grubego. Co ciekawe, autorzy badania zauważyli zależność pomiędzy większą aktywnością inflamasomu oraz wzmożoną produkcją IL-1 $\beta$, przy braku takiej zależności z produkcją IL-18 w tym przypadku. Najbardziej prawdopodobnymi przyczynami wiodącymi do wspomnianych różnic w stanie zwierząt był fakt istotnie mniejszej przepuszczalności bariery nabłonkowej w grupie myszy R258W oraz różnic w mikrobiocie jelitowej, która $\mathrm{w}$ przypadku grupy $\mathrm{z}$ nadaktywnym inflamasomem była istotnie uboższa w Actinobacteria oraz Verrucomicrobia. Autorzy wykazali, że bakterie jelitowe aktywując NLRP3 ${ }^{\mathrm{R} 258 \mathrm{~W}}$ doprowadzają do modulowanej przez inflamasom indukcji lokalnych limfocytów T regulatorowych Foxp3+. Ponadto, mutanty wykazywały niższe poziomy mediatorów prozapalnych takich jak CCL2, CCL5 czy IL-6 przy jednoczesnym wysokim stężeniu cytokin efektorowych charakterystycznych dla inflamasomu NLRP3.

Za naprawczy i ochronny efekt inflamasomu przed rozwojem NChZJ odpowiadają również cytokiny efektorowe, których aktywność prozapalna może stanowić nie tylko podłoże dla patologicznego zapalenia odpowiadającego za rozwój choroby, lecz również procesów naprawczych, utrzymujących integralność oraz homeostazę błony śluzowej przewodu pokarmowego.

IL-1 $\beta$ poprzez swoją rolę $w$ odpowiedzi immunologicznej uczestniczy $w$ promowaniu fagocytozy oraz zapobiega infekcjom przez bakterie kluczowe z punktu widzenia patogenezy oraz przebiegu NChZJ. Sztandarowym przykładem, zwłaszcza dla ChLC, jest infekcja Clostridium difficile, która wraz z NChZJ wydają się wzajemnie predysponować do współwystępowania [43]. Wykazano, że IL-1 $\beta$, komensalny mikrobiom jelita oraz białko adaptorowe ASC są kluczowymi elementami pętli pozytywnego sprzężenia zwrotnego chroniącej przed infekcją C. difficile [44]. Pętla ta obejmuje translokację komensalnych bakterii przez barierę jelitową, która jest rozszczelniona w przebiegu stanu zapalnego zależnego od infekcji, dzięki czemu dostarczany jest sygnał indukujący zależną od inflamasomu produkcję IL-1ß. W konsekwencji zachodzi chemotaksja neutrofili do miejsca infekcji i cykl się powtarza. Wykazano, że myszy genetycznie pozbawione białka ASC były wysoce wrażliwe na infek- cję C.difficile. Ponadto, brak ASC wpływał na dalszą translokację bakterii komensalnych i ich rozsiew w organizmie. Z punktu widzenia badan eksperymentalnych na modelach zwierzęcych ważne jest doniesienie o istotnym udziale IL$1 \beta \mathrm{w}$ odpowiedzi przeciwko Citrobacter rodentium [45].

IL-18 natomiast - poza działaniem prozapalnym o możliwym negatywnym wpływie na patogenezę NChZJ - ma również dobrze udokumentowaną rolę w utrzymywaniu homeostazy nabłonka błony śluzowej jelit za pośrednictwem działania IFNץ wydzielanego przez limfocyty $\mathrm{T}$ oraz komórki typu naturalnych zabójców (ang. natural killers, NK) [30]. Badania na komórkach T84 dostarczyły dowodów, że działanie IFNץ na nabłonek błony śluzowej jelit przebiega jako dwufazowy proces, w którym zaangażowana jest ścieżka przekaźnictwa wewnątrzkomórkowego Akt/Wnt/ $\beta$-katenina [46]. Z początku, w przebiegu fazy ostrej zapalenia na skutek działania IFNץ dominuje efekt proliferacyjny zależny od aktywności kinazy Akt fosforylującej $\beta$-kateninę. $\mathrm{Z}$ czasem proces ten zostaje zrównoważony przez zależną od aktywacji IFNץ wzmożoną apoptozę zależną od białka Dkk1, będącego inhibitorem ścieżki przewodnictwa Wnt/ $\beta$-katenina. Dzięki wzmożonej proliferacji komórek nabłonkowych w fazie ostrej z następczą ich apoptozą możliwe jest utrzymanie populacji komórkowej na stałym poziomie oraz regulacja homeostazy błony śluzowej jelit.

Ważnym aspektem sugerującym pozytywny wpływ aktywności inflamasomu na ryzyko wystąpienia NChZJ są również mutacje białka NOD2 (ang. nucleotide-binding oligomerization domain 2, znanego również jako CARD15), kodowanego przez pierwsze poznane locus (na chromosomie 16) związane z ChLC [47]. NOD2 należy do wewnątrzkomórkowych sensorów PAMP (zwłaszcza MDP), które są rozpoznawane dzięki obecnym w strukturze białka domenom LRR. Zwiększoną ekspresję tego białka wykazano jedynie leukocytach, co może być próbą kompensacji obniżonej funkcji genu NOD2/CARD15 przekładającej się na zmniejszenie odpowiedzi cytokinowej na wzorce molekularne pochodzące od mikrobiomu jelitowego [48]. Statystycznie, homozygotyczność pod względem hipofunkcyjnej mutacji NOD2 wiąże się nawet z 40-krotnie większym ryzykiem rozwoju choroby, natomiast heterozygotyczność z umiarkowanie większym ryzykiem sięgającym wartości pomiędzy od 2- do 4-krotnością wartości dla populacji ogólnej [2]. Początkowo przeprowadzone badanie wykazało powiązanie locus NOD2 ze zwiększonym ryzykiem rozwoju ChLC przy braku wpływu na WZJG. W 2012 roku znanych było 30 polimorfizmów NOD2 powiązanych z ChLC, jednak za aż $82 \%$ przypadków odpowiedzialne były zaledwie trzy z nich: Arg702Trp, Gly908Arg oraz Leuc1007insC [49].

Tabela 4. Inflamasom NLRP3 jako czynnik ochronny w patogenezie NChZJ.

\begin{tabular}{|c|c|c|}
\hline $\begin{array}{l}\text { Czynnik związany z } \\
\text { inflamasomem NLRP3 }\end{array}$ & Bezpośredni efekt aktywności & Rola w patogenezie NChZJ \\
\hline IL-1 $\beta$ & $\begin{array}{l}\text { Udział w przeciwdrobnoustrojowej } \\
\text { odpowiedzi immunologicznej }\end{array}$ & Zapobieganie infekcji C.difficile oraz C.rodentium (modele zwierzęce) \\
\hline Obecność IL-12 & $\begin{array}{l}\text { Indukcja IFNץ oraz aktywacja } \\
\text { szlaku Akt/Wnt/ } \beta \text {-katenina }\end{array}$ & $\begin{array}{l}\text { Proliferacji komórek nabłonkowych z następczą ich apoptozą } \\
\text { pozwalająca na regulację homeostazy błony śluzowej jelit }\end{array}$ \\
\hline NOD2 & $\begin{array}{l}\text { Uczestnictwo w odpowiedziach } \\
\text { immunologicznych na } \\
\text { mikrobiom jelitowy }\end{array}$ & $\begin{array}{l}\text { Unieczynniające mutacje wiążą się ze zwiększonym ryzykiem rozwoju } \\
\text { ChLC. Wykryto również mutacje predysponujące do WZJG. }\end{array}$ \\
\hline
\end{tabular}


Późniejsze badanie przeprowadzone na chińskiej populacji przez Zhang i in. [50] wskazało dwa polimorfizmy NOD2: rs10754558 oraz rs10925019 majace istotne powiązanie z WZJG przy jednoczesnym jego braku z ChLC. Wyniki te sugerują, że chociaż NOD2 jest najlepiej opisanym genem w kontekście NChZJ, nadal pozostaje wiele do odkrycia na jego temat.

Podsumowanie głównych aspektów ochronnej aktywności inflamasomu NLRP3 w patogenezie nieswoistych chorób zapalnych jelit przedstawiono w Tabeli 4.

\section{PYROPTOZA}

Osobnym tematem zasługującym na omówienie w kontekście roli inflamasomu w patogenezie NChZJ jest pyroptoza, stanowiąca nową perspektywę roli inflamasomu w NChZJ. Jest to mechanizm odporności wrodzonej w formie programowanej śmierci komórki związanej bezpośrednio z procesem zapalnym oraz bodźcami molekularnymi (DAMP i PAMP), docierającymi do receptorów rozpoznających wzorce. Zasadniczą różnicą pomiędzy pyroptozą a apoptozą jest prozapalny charakter pyroptozy, wynikający z uwolnienia cytokin prozapalnych, jak również ekspozycji na szersze działanie układu odpornościowego uwolnionych patogenów wewnątrzkomórkowych oraz ich wzorców molekularnych. Od nekrozy, trzeciego typu śmierci komórki, który również wywołuje stan zapalny, pyroptozę odróżnia przede wszystkim jej bardziej kontrolowany charakter. W molekularnym mechanizmie pyroptozy główną rolę odgrywają zależna od inflamasomu NLRP3 kaspaza 1, jak również kaspazy drogi niekanonicznej: 4, 5 (u ludzi) oraz 11 (model mysi) odpowiedzialne za pyroptozę również w komórkach niewykazujących ekspresji NLRP3. Modelową sytuacją, w której dochodzi do aktywacji drogi niekanonicznej jest infekcja bakteriami Gram-ujemnymi, kiedy to zawarty w nich LPS bezpośrednio aktywuje wymienione kaspazy [51]. W procesie pyroptozy substratem dla wymienionych wyżej kaspaz jest gasdermina D (GsdmD), która jednocześnie jest opor- na na działanie kaspaz związanych z procesem apoptozy. Uwolniona domena N-końcowa gasderminy (N-GsdmD) łączy się z błoną komórkową tworząc w niej pory, dzięki czemu zachodzi programowana śmierć komórki [52]. Ponadto, w przypadku niekanonicznej aktywacji pyroptozy, N-GsdmD odpowiada również za bezpośrednią aktywację inflamasomu NLRP3 i jego aktywności kanonicznej. Porównanie poszczególnych typów śmierci komórki przedstawiono w Tabeli 5, natomiast schemat procesu pyroptozy znajduje się na rycinie 3.

Istnieją badania wykazujące istotną rolę pyroptozy w patogenezie NChZJ. Yuan wraz z zespołem [56] zaobserwowali podwyższone poziomy ekspresji kaspazy 1, NLRP3 oraz GsdmD w biopsjach jelita $\mathrm{z}$ aktywnym procesem zapalnym w porównaniu ze zdrową tkanką. Ponadto, u pacjentów z aktywnym WZJG, u których wykazano obecność predysponujących do rozwoju choroby polimorfizmów genów TLR2 (ang. Toll-like receptor 2) oraz MDR1 (ang. multidrug resistance 1) zaobserwowano wzmożoną pyroptozę, co sugeruje istotny udział tego zjawiska w patogenezie NChZJ.

Ze względu na prozapalny charakter pyroptozy przypuszcza się, że nadmierna i źle kontrolowana może stanowić potencjalny mechanizm, w którym inflamasom aktywnie uczestniczy w patogenezie NChZJ oraz wpływa na jej przebieg. Stwarza to szansę wykorzystania pyroptozy jako celu leczenia schorzeń o podłożu zapalnym - wykazano już, że emulsja cholekalcyferolo-cholesterolowa łagodzi przebieg autoimmunologicznego zapalenia mięśnia sercowego poprzez hamowanie przekaźnictwa komórkowego odpowiedzialnego za pyroptozę [57]. Z drugiej strony warto zauważyć, że pyroptoza jako mechanizm odpowiedzi nieswoistej uczestniczy $w$ interakcjach $z$ mikroorganizmami znajdującymi się wewnątrz światła jelita chroniąc błonę śluzową przed infekcją i dysbiozą, które predysponują do rozwoju NChZJ. Z pewnością dalsze badania są potrzebne, aby dokładniej opisać rolę tego zjawiska w kontekście NChZJ.

Tabela 5. Porównanie mechanizmów śmierci komórki - pyroptozy, nekrozy oraz apoptozy (na podstawie [53]-[55])

\begin{tabular}{|c|c|c|c|}
\hline & Pyroptoza & Apoptoza & Nekroza \\
\hline Udział inflamasomu NLRP3 & Tak & $\mathrm{Nie}$ & $\mathrm{Nie}$ \\
\hline Indukcja stanu zapalnego & Tak & Nie & Tak \\
\hline Czynniki wywołujące & $\begin{array}{l}\text { Głównie infekcje } \\
\text { wewnątrzkomórkowe; element } \\
\text { odporności nieswoistej }\end{array}$ & $\begin{array}{l}\text { Czynniki wewnątrzkomórkowe } \\
\text { związane z uszkodzeniem komórki } \\
\text { - np. infekcje, uszkodzenie } \\
\text { materiału genetycznego }\end{array}$ & $\begin{array}{l}\text { Czynniki zewnątrzkomórkowe, } \\
\text { np. infekcje, uraz }\end{array}$ \\
\hline Czynniki inicjujące & $\begin{array}{l}\text { Kaspaza } 1 \text {, również } \\
\text { kaspaza } 4 / 5 \text { oraz } 11\end{array}$ & Kaspazy: 2, 8, 9 oraz 10 & Brak charakterystycznych \\
\hline Czynniki efektorowe & $\begin{array}{l}\text { Gasdermina D (domena } \\
\text { N-końcowa) }\end{array}$ & Kaspazy 3, 6, 7 & $\begin{array}{l}\text { Brak charakterystycznych, } \\
\text { uwolnione enzymy lizosomalne }\end{array}$ \\
\hline Jądro komórkowe & Nienaruszone & Pofragmentowane & $\begin{array}{l}\text { Zdegenerowane (piknoza, } \\
\text { karioliza, karioreksis) }\end{array}$ \\
\hline Obrzęk komórki & Tak & Nie & Tak \\
\hline
\end{tabular}




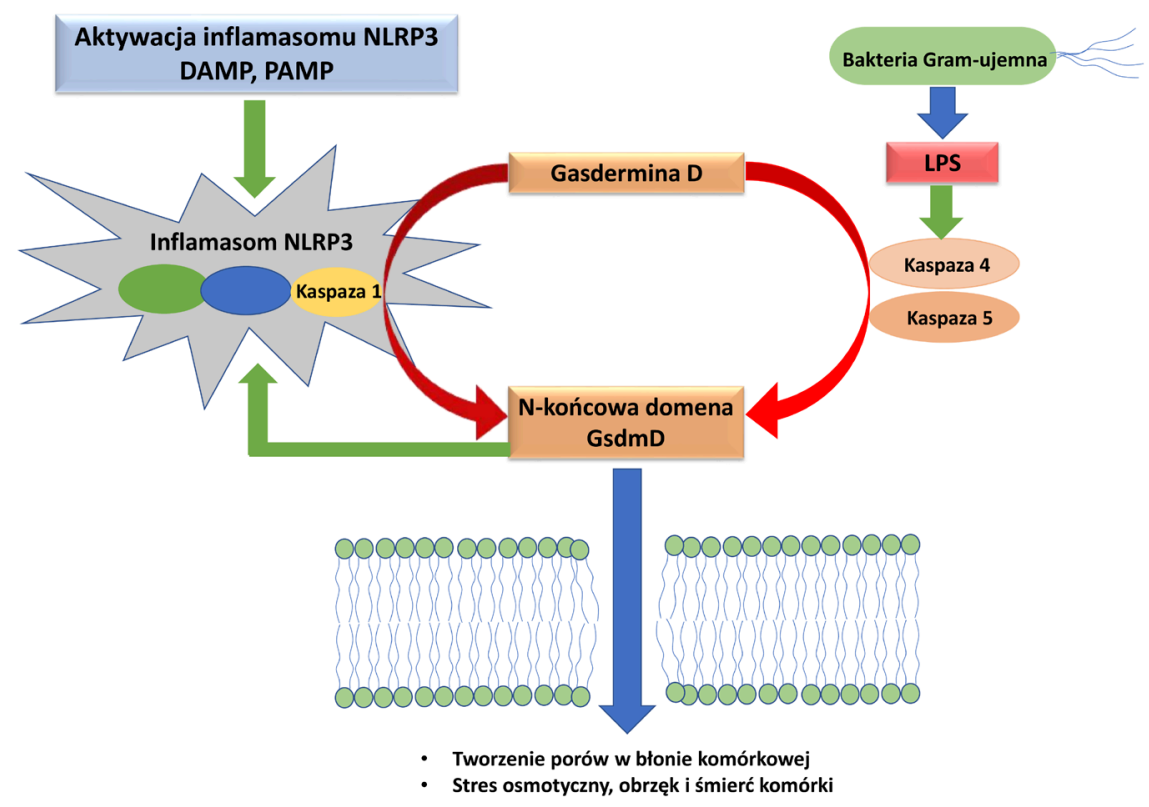

Rycina 3. Schemat przebiegu pyroptozy.

\section{PODSUMOWANIE}

Nie ulega wątpliwości, że inflamasom NLRP3 stanowi bardzo ważny czynnik determinujący kwestie predyspozycji, patogenezy oraz samego przebiegu NChZJ (Ryc. 4). Biorąc pod uwage wielofunkcyjność cytokin efektorowych oraz złożoność inflamasomu, najprawdopodobniej obydwa podejścia do jego roli w NChZJ - zarówno jako czynnika sprawczego, jak i ochronnego są równocenne i wzajemnie

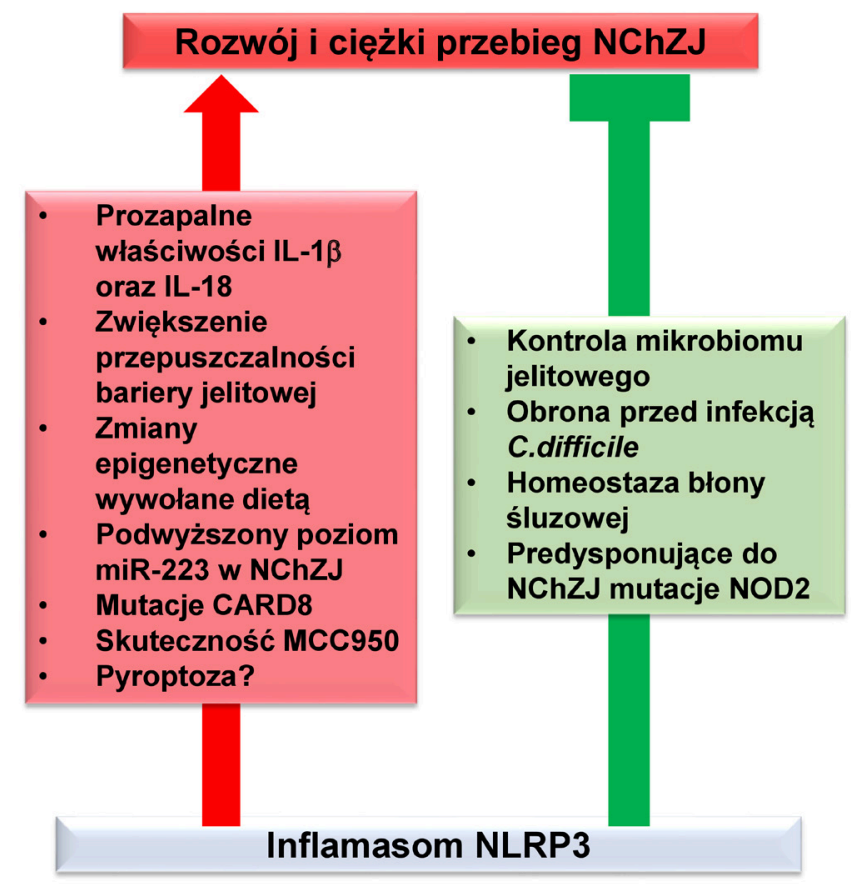

Rycina 4. Podsumowanie wpływu aktywności inflamasomu na patogenezę i przebieg NChZJ. się uzupełniają, co znajduje odzwierciedlenie w uzyskiwanych wynikach, które nie są jednoznaczne.

W praktyce inflamasom, jako kompleks również w znaczeniu funkcjonalnym, jest złożonym i trudnym do badania układem poddawanym regulacji przez szeroką gamę czynników molekularnych [58]. Podstawową trudność w badaniu inflamasomu stanowi fakt, że wśród czynników aktywujących inflamasom znajdują się również czynniki środowiskowe, a także mikrobiom jelitowy, na który duży wpływ ma m.in. styl i warunki życia pacjentów. Z tego powodu konieczne są dalsze badania, aby poprzez lepsze poznanie regulacji i aktywności inflamasomu możliwa była lepsza standaryzacja modeli eksperymentalnych oraz trafniejsza interpretacja uzyskanych wyników. Mogłoby to doprowadzić do poszerzenia gamy metod terapeutycznych stosowanych w leczeniu NChZJ.

\section{PIŚMIENNICTWO}

- Hanauer SB (2006) Inflammatory bowel disease: Epidemiology, pathogenesis, and therapeutic opportunities. Inflammatory Bowel Diseases, 12: S3-9

- Ananthakrishnan AN (2015) Epidemiology and risk factors for IBD. Nat Rev Gastroenterol Hepatol 12: 205-217

- Hendrickson BA, Gokhale R, Cho JH (2002) Clinical aspects and pathophysiology of inflammatory bowel disease. Clin Microbiol Rev 15: 79-94

- Zhen Y, Zhang H (2019) NLRP3 inflammasome and inflammatory bowel disease. Front Immunol 10: 1-10

- Latz E, Xiao TS, Stutz A (2013) Activation and regulation of the inflammasomes. Nat Rev Immunol 13: 397-411

- Franchi L, Eigenbrod T, Núñez G (2009) Cutting edge: TNF-alpha mediates sensitization to ATP and silica via the NLRP3 inflammasome in the absence of microbial stimulation. J Immunol 183: 792-796

- Yang J, Wise L, Fukuchi KI (2020) TLR4 cross-talk with NLRP3 inflammasome and complement signaling pathways in Alzheimer's disease. Front Immunol 11: 724 
- Franchi L, Muñoz-Planillo R, Núñez G (2012) Sensing and reacting to microbes through the inflammasomes. Nat. Immunol 13: 325-332

- Abais JM, Xia M, Zhang Y, Boini KM, Li PL (2015) Redox regulation of NLRP3 inflammasomes: ROS as Trigger or effector? Antioxidants Redox Signal 22: 1111-1129

- Kummer JA, Broekhulzen R, Everett H, Agostnini L, Kuijk L, Martinon F, van Bruggen R, Tschopp J (2007) Inflammasome components NALP 1 and 3 show distinct but separate expression profiles in human tissues suggesting a site-specific role in the inflammatory response. J Histochem Cytochem Off J Histochem Soc 55: 443-452

- Ruiz PA, Moron B, Becker HM, Lang S, Atrott K, Spalinger MR, Scharl M, Wojtal KA, Fishbeck-Terhalle A, Frey-Wagner I, Hausmann M, Kraemer T, Rogler G (2017) Titanium dioxide nanoparticles exacerbate DSS-induced colitis: role of the NLRP3 inflammasome. Gut 66: 1216-1224

- Yao X, Zhang C, Xing Y, Xue G, Zhang Q, Pan F, Wu G, Hu Y, Guo Q, Lu A, Zhang X, Zhou R, Tian Z, Zeng B, Wei H, Strober W, Zhao L, Meng G (2017) Remodelling of the gut microbiota by hyperactive NLRP3 induces regulatory T cells to maintain homeostasis. Nat Commun 8: 1-17

- Zaki MH, Lamkanfi M, Kanneganti TD (2011) The Nlrp3 inflammasome: contributions to intestinal homeostasis. Trends Immunol 32: 171-179

- Muñoz-Planillo R, Kuffa P, Martínez-Colón G, Smith BL, Rajendiran TM, Núñez G (2013) K+ efflux is the common trigger of NLRP3 inflammasome activation by bacterial toxins and particulate matter. Immunity 38: 1142-1153

- Zhou R, Tardivel A, Thorens B, Choi I, Tschopp J (2010) Thioredoxin-interacting protein links oxidative stress to inflammasome activation. Nat Immunol 11: 136-140

- Yu X, Lan P, Hou X, Han Q, Lu N, Li T, Jiao C, Zhang J, Zhang C, Tian Z (2017) HBV inhibits LPS-induced NLRP3 inflammasome activation and IL-1 $\beta$ production via suppressing the NF-KB pathway and ROS production. J Hepatol 66: 693-702

- Sharif H, Wang L, Wang WL, Magupalli VG, Andreeva L, Qiao Q, Hauenstein AV, Wu Z, Nunez G, Mao Y, Hao Y (2019) Structural mechanism for NEK7-licensed activation of NLRP3 inflammasome. Nature 570: 338-343

- Lazaridis LD, Pistiki AP, Giamarellos-Bourboulis EJ, Georgitsi M, Damoraki G, Polymeros D, Dimitriadis GD, Triantafyllou K (2017) Activation of NLRP3 Inflammasome in inflammatory bowel disease: differences between Crohn's disease and ulcerative colitis. Dig Dis Sci 62: 2348-2356

- Gionchetti P, Campieri M, Belluzzi A, Tampieri M, Bertinelli E, Brignola C, Ferretti M, Boni P, Iannone P, Miglioli M (1992) Interleukin 1 beta (IL-1 beta) release from fresh and cultured colonic mucosa in patients with ulcerative colitis (UC). Agents Actions Spec: C50-2

- Bauer C, Duewell P, Lehr HA, Endres S, Schnurr M (2012) Protective and aggravating effects of Nlrp3 inflammasome activation in IBD models: influence of genetic and environmental factors. Dig Dis 30: 82-90

- Mahida YR, Wu K, Jewell DP (1989) Enhanced production of interleukin 1-beta by mononuclear cells isolated from mucosa with active ulcerative colitis of Crohn's disease. Gut 30: 835-838

- Jones GR, Bain CC, Fenton TM, Kelly A, Brown SL, Ivens AC, Travis MA, Cook PC, MacDonald AS (2018) Dynamics of colon monocyte and macrophage activation during colitis. Front Immunol 9: 2764

- Christ A, Gunther P, Lauterbach MAR, Duewell P, Biswas D, Pelka K, Scholz CJ, Oosting M, Haendler K, Baßler K, Klee K, Schulte-Schrepping J, Ulas T, Moorlag SJCFM, Kumar V, Park MH, Joosten LAB, Groh LA, Riksen NP, Espevik T, Schlitzer A, Li Y, Fitzgerald ML, Netea MG, Schultze JL, Latz E (2018) Western diet triggers NLRP3-dependent innate immune reprogramming. Cell 172: 162-175

- Germano G, Allavena P, Mantovani A (2008) Cytokines as a key component of cancer-related inflammation. Cytokine 43: 374-379

- Santarlasci V, Cosmi L, Maggi L, Liotta F, Annunziato F (2013) IL-1 and T helper immune responses. Front Immunol 4: 182
- Brand S (2009) Crohn's disease: Th1, Th17 or both? The change of a paradigm: new immunological and genetic insights implicate Th17 cells in the pathogenesis of Crohn's disease. Gut 58: 1152-1167

- Coccia M, Harrison OJ, Schiering C, Asquith MJ, Becher B, Powrie F, Maloy KJ (2012) IL-1 $\beta$ mediates chronic intestinal inflammation by promoting the accumulation of IL-17A secreting innate lymphoid cells and CD4(+) Th17 cells. J Exp Med 209: 1595-1609

- Williams MA, O'Callaghan A, Corr SC (2019) IL-33 and IL-18 in inflammatory bowel disease etiology and microbial interactions. Front Immunol 10: 1091

- Nemeth ZH, Bogdanovski DA, Barratt-Stopper P, Paglinco SR, Antonioli L, Rolandelli RH (2017) Crohn's disease and ulcerative colitis show unique cytokine profiles. Cureus 9: e1177

- Nakanishi K, Yoshimoto T, Tsutsui H, Okamura H (2001) Interleukin-18 is a unique cytokine that stimulates both Th1 and Th2 responses depending on its cytokine milieu. Cytokine Growth Factor Rev 12: $53-72$

- Nowarski R, Jackson R, Gagliani N, de Zoete MR, Palm NW, Bailis W, Low JS, Harman CCD, Graham M, Elinav E, Flavell RA (2015) Epithelial IL-18 equilibrium controls barrier function in colitis. Cell 163: 1444-1456

- Salcedo R, Worschech A, Cardone M, Jones Y, Gyulai Z, Dai RM, Ma W, Haines D, O'hUigin C, Marincola FM, Trinchieri G (2010) MyD88-mediated signaling prevents development of adenocarcinomas of the colon: role of interleukin 18. J Exp Med 207: 1625-1636

- Pizarro TT, Michie MH, Bentz M, Woraratanadharm J, Smith Jr MF, Foley E, Moskaluk CA, Bickston SJ, Cominelli F (1999) IL-18, a novel immunoregulatory cytokine, is up-regulated in Crohn's disease: expression and localization in intestinal mucosal cells. J Immunol 162: 6829-6835

- Bruchard M, Rebe C, Derangere V, Togbe D, Ryffel B, Boidot R, Humblin E, Hamman A, Chalmin F, Berger H, Chevriaux A, Limagne E, Apetoh L, Vegran F, Ghiringhelli (2015) The receptor NLRP3 is a transcriptional regulator of TH2 differentiation. Nat Immunol 16: 859-870

- Di Leo V, Yang PC, Berin MC, Perdue MH (2002) Factors regulating the effect of IL-4 on intestinal epithelial barrier function. Int Arch Allergy Immunol 129: 219-227

- Haneklaus M, Gerlic M, Kurowska-Stolarska M, Rainey AA, Pich D, McInnes IB, Hammerschmidt W, O'Neill LAJ, Masters SL (2012) Cutting edge: miR-223 and EBV miR-BART15 regulate the NLRP3 inflammasome and IL-1 $\beta$ production. J Immunol 189: 3795-3799

- Neudecker V, Haneklaus M, Jensen O, Khailova L, Masterson JC, Tye H, Biette K, Jedlicka P, Brodsky KS, Gerich ME, Mack M, Robertson AAB, Cooper MA, Furuta GT, Dinarello CA, O'Neill LA, Eltzschig HK, Masters SL, McNamee EN (2017) Myeloid-derived miR-223 regulates intestinal inflammation via repression of the NLRP3 inflammasome. J Exp Med 214: 1737-1752

- Ito S, Hara Y, Kubota T (2014) CARD8 is a negative regulator for NLRP3 inflammasome, but mutant NLRP3 in cryopyrin-associated periodic syndromes escapes the restriction. Arthritis Res Ther 16: R52

- Mao L, Kitani A, Similuk M, Oler AJ, Albenberg L, Kelsen J, Aktay A, Quezado M, Yao M, Montgomery-Recht K, Fuss IJ, Strober W (2018) Loss-of-function CARD8 mutation causes NLRP3 inflammasome activation and Crohn's disease. J Clin Invest 128: 1793-1806

- Romberg N, Moussawi KA, Nelson-Williams C, Stiegler AL, Loring E, Choi M, Overton J, Meffre E, Khokha MK, Huttner AJ, West B, Podoltsev NA, Boggon TJ, Kazmierczak BI, Lifton RP (2014) Mutation of NLRC4 causes a syndrome of enterocolitis and autoinflammation. Nat Genet 46: 1135-1139

- Tapia-Abellán A, Angosto-Bazarra A, Martinez-Banalocha H, de Torre-Minguela C, Ceron-Carrasco JP, Perez-Sanchez H, Arostegui JI, Pelegrin P (2019) MCC950 closes the active conformation of NLRP3 to an inactive state. Nat Chem Biol 15: 560-564

- Perera AP, Fernando R, Shinde T, Gundamaraju R, Southam B, Sohal SS, Robertson AAB, Schroder K, Kunde D, Eri R (2018) MCC950, a specific small molecule inhibitor of NLRP3 inflammasome attenuates colonic inflammation in spontaneous colitis mice. Sci Rep 8: 8618 
- Nitzan O, Elias M, Chazan B, Raz R, Saliba W (2013) Clostridium difficile and inflammatory bowel disease: role in pathogenesis and implications in treatment. World J Gastroenterol 19: 7577-7585

- Hasegawa M, Kamada N, Jiao Y, Liu MZ, Núñez G, Inohara N (2012) Protective role of commensals against Clostridium difficile infection via an IL-1 $\beta$-mediated positive-feedback loop. J Immunol 189: 3085 3091

- Alipour M, Lou Y, Zimmerman D, Bording-Jorgensen MW, Sergi C, Liu JJ, Wine E (2013) A balanced IL-1 $\beta$ activity is required for host response to Citrobacter rodentium infection. PLoS One 8: e80656

- Nava P, Koch S, Laukoetter MG, Lee WY, Kolegraff K, Capaldo CT, Beeman N, Addis C, Gerner-Smidt K, Neumaier I, Skerra A, Li L, Parkos CA, Nusrat A (2010) Interferon-gamma regulates intestinal epithelial homeostasis through converging beta-catenin signaling pathways. Immunity 32: 392-402

- Hugot JP, Chaaillard M, Zouali H, Lesage S, Cezard JP, Belaiche J, Almer S, Tysk C, O'Morain CA, Gassull M, Binder V, Finkel Y, Cortot A, Modigliani R, Laurent-Puig P, Gower-Rousseau C, Macry J, Colombel JF, Sahbatou M, Thomas G (2001) Association of NOD2 leucine-rich repeat variants with susceptibility to Crohn's disease. Nature 411: 599-603

- Zatorski H, Sałaga M, Zielińska M, Fichna J (2015) Czynniki genetyczne w patogenezie, przebiegu i leczeniu nieswoistych chorób zapalnych jelit. Postepy Hig Med Dosw 69: 335-344

- Tsianos EV, Katsanos KH, Tsianos VE (2012) Role of genetics in the diagnosis and prognosis of Crohn's disease. World J Gastroenterol 18: 105-118

- Zhang H, Wang Z, Lu X, Wang Y, Zhong J, Liu J (2014) NLRP3 gene is associated with ulcerative colitis (UC), but not Crohn's disease (CD), in Chinese Han population. Inflamm. Res. Off. J. Eur. Histamine Res Soc 63: 979-985,

- Man SM, Karki R, Kanneganti TD (2017) Molecular mechanisms and functions of pyroptosis, inflammatory caspases and inflammasomes in infectious diseases. Immunol Rev 277: 61-75

- Shi J, Gao W, Shao F (2017) Pyroptosis: Gasdermin-Mediated Programmed Necrotic Cell Death. Trends Biochem Sci 42: 245-254

- Fink SL, Cookson BT (2005) Apoptosis, pyroptosis, and necrosis: Mechanistic description of dead and dying eukaryotic cells. Infect Immun 73: 1907-1916

- de Vasconcelos NM, Van Opdenbosch N, Van Gorp H, Parthoens E, Lamkanfi M (2019) Single-cell analysis of pyroptosis dynamics reveals conserved GSDMD-mediated subcellular events that precede plasma membrane rupture. Cell Death Differ 26: 146-161

- Chávez-Morales RM, Jaramillo-Juárez F, Posadas del Río FA, Reyes-Romero MA, Rodríguez-Vázquez ML, Martínez-Saldaña MC (2011) Protective effect of Ginkgo biloba extract on liver damage by a single dose of $\mathrm{CCl}(4)$ in male rats. Hum Exp Toxicol 30: 209-216

- Yuan YY, Xie KX, Wang SL, Yuan LW (2018) Inflammatory caspase-related pyroptosis: mechanism, regulation and therapeutic potential for inflammatory bowel disease. Gastroenterol Rep 6: 167-176

- Liu N, Su H, Zhang Y, Liu Z, Kong J (2017) Cholecalciterol cholesterol emulsion attenuates experimental autoimmune myocarditis in mice via inhibition of the pyroptosis signaling pathway. Biochem Biophys Res Commun 493: 422-428

- Yi YS (2018) Role of inflammasomes in inflammatory autoimmune rheumatic diseases. Korean J Physiol Pharmacol Off J Korean Physiol Soc Korean Soc Pharmacol 22: 1-15

\title{
The NLRP3 inflammasome as causative and protecting factor in pathogenesis of inflammatory bowel diseases
}

\section{Mikołaj Świerczyński, Jakub Fichna ${ }^{\natural}$}

Department of Biochemistry, Faculty of Medicine, Medical University of Lodz, Lodz, Poland

${ }^{\square}$ Corresponding author: Jakub.fichna@umed.lodz.pl

Key words: Inflammasome NLRP3, Inflammatory bowel diseases, Crohn's disease, ulcerative colitis

\begin{abstract}
Inflammatory bowel diseases (IBD) are a group of chronic and globally appearing conditions that significantly decrease patients' quality of life. The main representatives of IBD are Crohn's disease and ulcerative colitis. Although the etiology of IBD is still not fully understood, the NLRP3 inflammasome is one of the most promising targets of research in this field. The NLRP3 inflammasome is a functional complex, which is activated in damage- and pathogen-associated molecular patterns-dependent manner and is responsible for production of proinflammatory interleukin(IL)-1 $\beta$ and IL-18, because of which it participates in the inflammatory process underlying IBD. However, in recent years the NLRP3 inflammasome has gained attention as a potential protective factor against IBD being involved in maintaining homeostasis of intestinal mucosa and controlling intestinal microbiome. In our review we discuss the role of NLRP3 inflammasome in IBD pathogenesis as both causative and protecting factor.
\end{abstract}

